\title{
Disinfection of Orange Seeds to Reduce Citrus Canker Dissemination and Improve Germination
}

\author{
Asma Akbar (Corresponding Author) \\ Mid-Florida Research and Education Centre, Department of Plant Pathology, University of \\ Florida/Institute of Food and Agricultural Sciences, 2725 Binion Rd, Apopka, FL 32703; \\ Crop Diseases Research Institute, National Agriculture Research Centre Islamabad
}

\section{Shehzad Asad}

Crop Diseases Research Institute, National Agriculture Research Centre Islamabad

Zahoor Ahmad

Adaptive Research Program Quetta Baluchistan

Azra Nadeem

Ameer Muhammad Khan Campus, The university of Agriculture Peshawar Pakistan

Shehla Awan

NIGAB, National Agriculture Research Centre Islamabad

Received: July 29, 2020

doi:10.5296/jas.v8i4.17448
Accepted: August 27, 2020

Published: Sep. 9, 2020

URL: https://doi.org/10.5296/jas.v8i4.17448

\begin{abstract}
We evaluated chemo and thermotherapy for decontaminating orange seeds against the bacteria Xanthomonas citri subsp. citri (Xcc), a quarantine and economically important disease worldwide. We infected orange (cv. Valencia) seeds with bacterial inoculum and studied the potential of three different methods i.e. surface sterilization with bleach, disinfection with plant preservative mixture, and hot water treatment to eliminate the bacteria.
\end{abstract}


Our findings showed that the hot water, bleach $(\mathrm{NaOCl})$, and a commercially available mixture of antifungal and antibacterial compounds known as Plant Preservative Mixture (PPM) were very effective in eliminating most bacterial contamination from orange seeds. Our results also showed that treatment with bleach and hot water treatment enhanced seed germination and seedling vigor. Germination rate ranged from 18.51 to $77.78 \%, 7.41$ to $62.96 \%$ and 13.33 to $66.67 \%$ for bleach, PPM and hot water treatments, respectively. Seedling height ranged from 4.28 to $6.63 \mathrm{~cm}, 4.17$ to $5.94 \mathrm{~cm}$ and 3.42 to $5.99 \mathrm{~cm}$ for bleach, PPM and hot water treatment, respectively. Findings of this study will provide impactful and practical methods for an economical and robust seed decontamination method.

Keywords: citrus canker, Thermotherapy, Plant preservative mixture, Xanthomonas citri

\section{Introduction}

Citrus canker is a devastating disease of citrus and citrus relative worldwide (Ference et al., 2018) The disease causes huge economic losses to the citrus industry across the world in terms of quality and quantity of fruit. There also is the cost involved in its prevention and control. Although there are many strategies to eradicate and manage citrus canker, the disease still remains a threat to all citrus-growing areas of the world (Canteros, 2004).

The causal agent of citrus canker Xanthomonas citri subsp. citri (Xcc), is a rod-shaped gram-negative bacterium, motile by single polar flagellum measuring 1.5 to $2.0 \times 0.5$ to 0.75 $\mu \mathrm{m}$. The bacteria share many biochemical and physiological properties with other member of the genus. The pathogen may be isolated on potato dextrose agar (PDA) or NA medium at $\mathrm{pH}$ 6.8, producing creamy-yellow to straw-yellow colonies respectively (Gabriel, Kingsley, Hunter, \& Gottwald, 1989).

At the initiation of the disease small lesions appear as raised, light yellow, sponge like eruptions on different parts of the tree including leaves, twigs, and fruits. Later the small lesions progressively expand and attain different sizes over several months. With disease progression, the erupted lesions collapse, and brown structures appear in their center. These brown structures later form crater-like appearance. The edges of the lesions remain raised above the surface of host tissue and the area around the raised portion of the lesion may have a water-soaked appearance. Yellow halos encircle these lesions at the advance of disease (Gottwald, Graham, \& Schubert, 2002). It is reported that these erupted lesions remain spongy in drier conditions such as in a greenhouse. However, in humid and rainy seasons, they increase in size and turn brown giving a water-soaked appearance. The size of these lesions varies from 5 to $10 \mathrm{~mm}$, depending on the susceptibility of the host plant and environmental condition (Brunings \& Gabriel, 2003). Introduction of the disease in a new area occurs through the distribution of infected citrus seedlings and fruits, while local dissemination occurs by rainwater or irrigation water running over the surfaces of lesions, therefore the disease is more prevalent in areas of high temperature, strong wind, and heavy rainfall (Gottwald et al., 2002).

The primary source of inoculum for disease initiation is the survival of $X$. citri from season to season. The bacteria reside in canker lesion on leaf or stem. When there is free moisture the 
bacteria ooze out of the lesions. During rainy weather, windblown rain carries the inoculum from these lesions to the new susceptible hosts and infect new plants through wounds and stomata (Thakre, Soni, Gour, Vishwakarma, \& Jashwani, 2017). Different approaches such as biological, cultural, and chemical control have been used to manage the disease. However, among these copper-based bactericides are the most prominent ones for citrus canker management. These chemical treatments often lead to environmental hazards and contamination of soil and emergence of resistant strains. In view of these constraints an environmentally friendly and easy to adopt approach needs to be developed and implemented in a disease management program (Canteros, 2004).

Besides seeds are not the major source of disease spread, however, rootstock germinated from seeds obtained from trees harboring potent infection can lead to spread of the disease. Keeping this in focus, the objective of this research was to develop an economical and easy to implement seed decontamination method for removing $X$. citri bacteria from seeds without loss of seed viability. For this purpose, the following different procedures were tested: 1) surface sterilization using bleach $(\mathrm{NaOCl}), 2)$ Plant Preservative Mixture (PPM), 3) hot water.

\section{Material and Methods}

Assessment of natural orange seed contamination and artificial inoculation of orange seeds with Xanthomonas citri subsp. citri

The seeds of orange cultivar Valencia were obtained from Philip Rucks Citrus Nursery Inc Florida USA. These seeds were plated directly on Nutrient Agar medium (NA) plates and some were rinsed with distilled water, $5 \mathrm{ml}$ from this rinsed water was then dispersed on four different growth media.

In another set of experiment seeds were squeezed out from infected and uninfected orange fruits to assess the effect of canker infection from orange fruit on seeds. These seeds were then plated on NA plates for the presence of bacterial contamination (Orbović, Dutt, \& Grosser, 2013). Orange seeds obtained from healthy fruits were completely free of any Xcc contamination. Some healthy seeds were artificially inoculated with Xcc. For this purpose, bacteria were grown in $5 \mathrm{ml}$ liquid nutrient broth (LB) media. After $24 \mathrm{~h}$ the bacterial culture was diluted to 0.002 (using Bio-Rad Smart Spec 3000 spectrophotometer) in 250mL sterile water and orange seeds were soaked in it for 1 hour. After one hour of soaking, seeds were removed from bacterial culture, and were blotted dry on sterile paper towel. The seeds were covered and were incubated for $24 \mathrm{~h}$ incubation period.

Contaminated seeds were placed on sterile filter papers and were let dry at room temperature for $24 \mathrm{~h}$. Seeds were rinsed in sterile distilled water and serial dilutions of the rinsed water were plated for bacterial count. Similarly, intact seeds were also placed on NA medium for confirmation of contamination. 


\section{Surface sterilization with bleach}

Commercial bleach $(\mathrm{NaOCl} 5.2 \%)$ was used at a dilution of $10-20 \%$ resulting in a $0.5-1 \%$ final $\mathrm{NaOCl}$ concentration. Artificially inoculated seeds were treated with five different $\mathrm{NaOCl}$ concentrations $(10 \%, 20 \%, 30 \%, 40 \%$ or $50 \%)$ along with water as a control $(0 \%$ $\mathrm{NaOCl})$.

Seeds treated with bacteria were placed in sterile 50-ml falcon tubes (40 seeds/tube). Twenty-five $\mathrm{ml}$ bleach at appropriate concentration (10, 20, 30, 40, and 50\%) was added to each tube. Tubes were continuously shaken on a shaker for one hour. Afterward some bleach solution was poured off and tubes were rinsed with distilled water three times. Seeds were transferred to sterile paper towels in a hood to remove excess moisture.

To determine the disinfection efficiency of each bleach treatment, treated seeds were divided into three lots consisting of 10 seeds per lot. Each lot was plated on NA medium for evidence of bacterial growth. Similarly, $200 \mu \mathrm{l}$ water from the last rinses of each concentration were plated on 5 NA plates. Plates were incubated at room temperature $\left(25^{\circ} \mathrm{C}\right)$ and photographed after $48 \mathrm{~h}$ for counting colony-forming units (CFU).

\section{Disinfection with Plant Preservative Mixture (PPM $\left.{ }^{\mathrm{TM}}\right)$}

Seeds treated with bacteria were placed in sterile $50 \mathrm{ml}$ tubes (40 seeds/tube). The appropriate concentration of PPM $(0,1,2,3,6$ and $10 \%)$ was added to each tube. The seeds were soaked in suspension for one hour while continuously shaking. After one hour, the liquid was poured off and tubes were rinsed with water. Seeds were poured on sterile paper towels in a hood to air dry.

Three lots of 10 seeds from each treatment were placed on NA medium, and kept at $30^{\circ} \mathrm{C}$ for incubation. Seeds were observed for contamination every day for the first two weeks and then every week for the next two months. To find out the potent infection in seeds, one seed from each treatment above was placed in a sterile $15 \mathrm{ml}$ tube, ( 5 reps). Five $\mathrm{ml}$ of sterile water was added to each tube. Tubes were vortexed right before removing 200ul of the liquid. The 200ul was placed on NA plate and was spread using L Bar on plate spinner in the hood. Plates were placed on a lab bench, for $48 \mathrm{~h}$. After $48 \mathrm{~h}$ pictures were taken of each plate to later count the bacterial colonies.

To find out the optimal concentration of bleach and PPM that resulted in the least seed lethality, treated seeds were plated on seed germination medium. Each treatment consisted of three replications each consisting of 20 seeds. Seeds were observed for any contamination every day for the first two weeks and then every week for the next three months.

\section{Hot water treatment}

Orange seeds were soaked for an hour in 0.0025 diluted bacterial culture in $250 \mathrm{ml}$ sterile water. After one hour the seeds were removed from liquid and placed on sterile paper towels on tray for $24 \mathrm{~h}$ to dry.

Water baths were set at the following temperatures including room temperature for 
comparison; $110^{\circ} \mathrm{F}, 125^{\circ} \mathrm{F}, 135^{\circ} \mathrm{F}, 145^{\circ} \mathrm{F}$, with time increment of $5,10,15$, and 20 minutes. Ten seeds treated with bacteria were placed in a $50 \mathrm{ml}$ sterile tube, sterile water was warmed, and $20 \mathrm{ml}$ sterile water was distributed into each tube. Every treatment was replicated three times. Tubes were placed in a water bath and pulled out at $5 \mathrm{~min}$ intervals, and water was removed from each tube for plating.

The water was removed from tubes and 200 ul of water from each treatment was also pipetted onto an NA plate and spread with an L Bar. Plates were placed on lab counter, and pictures were taken at $48 \mathrm{~h}$.Another $20 \mathrm{ml}$ of sterile water was added to each tube and shaken for a few second to rinse the seeds.

Ten seeds from each treatment $\left(110^{\circ} \mathrm{F}, 125^{\circ} \mathrm{F}, 135^{\circ} \mathrm{F}, 145^{\circ} \mathrm{F}\right.$ and room temperature $\left.86^{\circ} \mathrm{F}\right)$ with 3 replications were planted in cell packs and placed in a controlled environment, for germination count.

To assess the bacterial CFU for each treatment, cells were serially diluted in NA plates and incubated at $30^{\circ} \mathrm{C}$ for $48 \mathrm{~h}$. Manual counting of the bacterial CFU was performed with help of a hand counter. Counted CFU were marked with a pen on the plate cover to discriminate counted from uncounted colonies.

\section{Statistical analyses of data}

The data were analyzed by one-way analysis of variance (ANOVA). Means and standard error for the number of contaminated and germinated seeds were performed with Microsoft excel (2013) and STATISTIX software (8.1) (Analytical Software, Tallahassee, FL, USA). Differences between the means were tested by using Fischer's least significant difference (LSD) at 0.05 probability level. Each experiment was performed in triplicate, and data were averaged for analysis.

\section{Results and Discussion}

\section{Assessment of natural orange seed contamination and artificial inoculation of orange} seeds with Xanthomonas citri subsp. citri

Xanthomonas citri subsp. citri is one of the most devastating causal organisms of citrus canker and is an alarming threat to citrus/orange fruit producing countries. Although the application of different copper-based bactericides and antibiotics decreases the citrus canker they are very hazardous to the environment and expensive (Mei, Zhou, Li, \& Zhou, 2020). In this research we performed comparative studies to assess the potential of different treatments (chemo and thermotherapy) in the management of the bacteria.

Seeds from non-inoculated and artificially inoculated orange fruit were squeezed out to assess the effect of citrus canker infection from orange fruit on seeds (Fig. 1A \& B). Then these seeds were placed on NA medium for 7 days at $30^{\circ} \mathrm{C}$ to check the bacterial contamination. Two days after plating, no CFUs appeared on plates with seeds from non-contaminated fruit (Fig. 1C \& D). Seven days after plating, besides several distinct colonies of X. citri, many different bacterial and fungal colonies with distinct morphologies appeared from contaminated fruits, which could represent environmental contaminations or endophytes 
present in orange fruits, $(\mathbf{F i g} .1 \mathbf{E} \& \mathbf{F})$. These results indicate that seeds from infected fruit are usually not heavily contaminated with $X$. citri. Results from these experiments showed that orange seeds were successfully contaminated with $X$. citri subsp. citri.
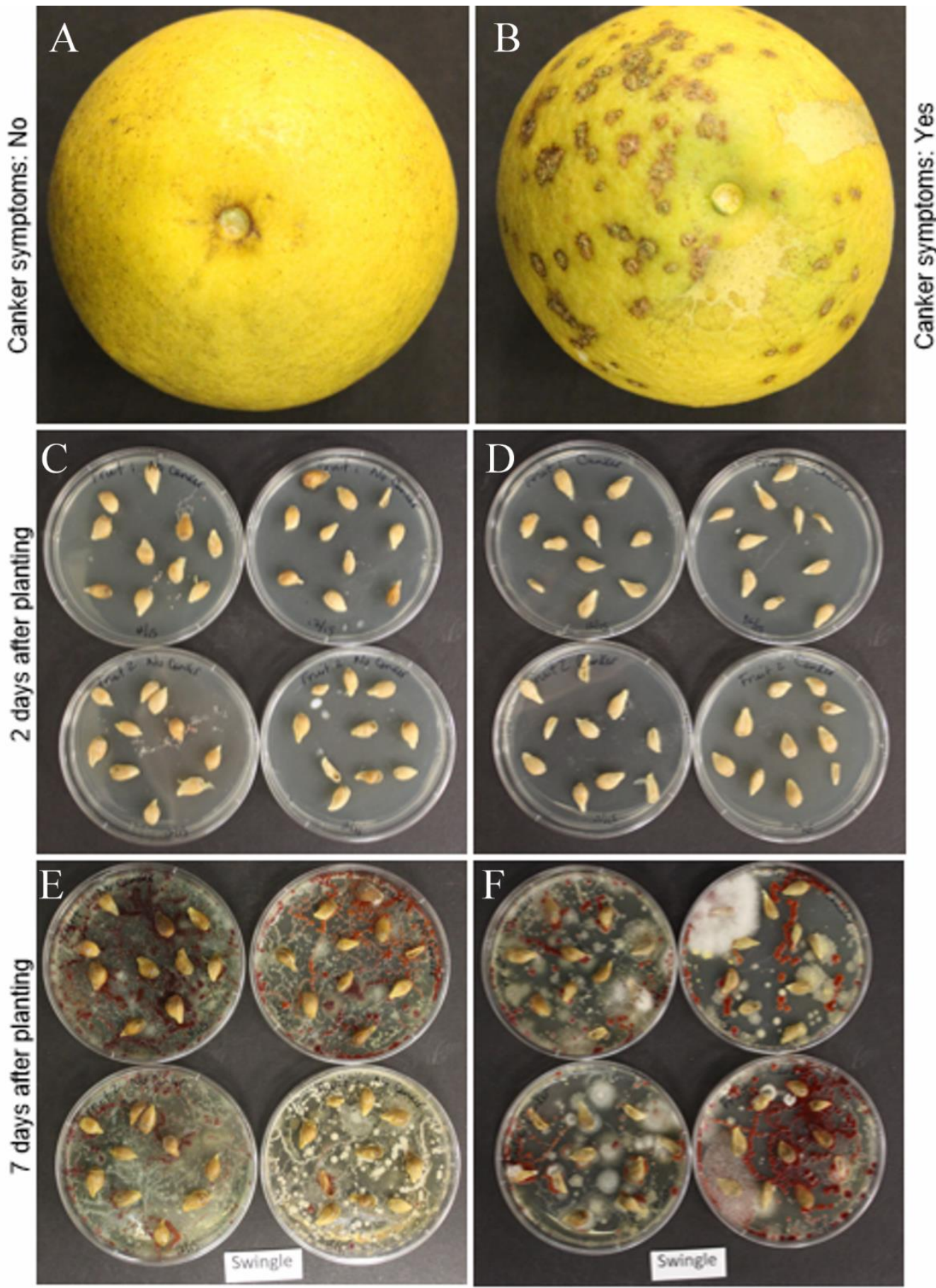

Figure 1. Uninfected (Left) and diseased (Right) swingle fruit; (A) Swingle fruit with no canker symptoms; (B) Artificially inoculated swingle fruit with canker symptoms; (C-D) Seeds of uninfected and infected swingle fruit after 2 days of incubation; (E-F) Seeds of uninfected and infected swingle fruit after 7 days of incubation 


\section{Macrothink \\ Journal of Agricultural Studies \\ ISSN 2166-0379 \\ 2020, Vol. 8, No. 4}

\section{Surface sterilization with sodium hypochlorite}

Different concentrations of bleach were screened against the infected seeds of $X$. citri. It was reported that bleach $(\mathrm{NaOCl})$ could offer a potential alternative to many other procedures used for the decontamination of orange seeds. All the concentration of bleach (10, 20, 30, 40, and 50\%) used in this research efficiently reduced the contamination of seed with slight differences. There were no bacterial colonies after $48 \mathrm{~h}$ of incubation in comparison with control (Fig. 2A-F). However, after 3 days of incubation there were some bacterial contamination (Fig. 2G-L). After 10 days of incubation bacterial growth was found even in $50 \%$ concentration of bleach (Fig. 2M-R). Bleach is used as a common sterilizing agent to disinfect many plants. In previous reports bleach could be an effective sterilizing agent for the leaves of agarbl (Aquilaria sinensis) and (Aquilaria crasna) (Okudera \& Ito, 2009). In our study, bleach showed potential in decontamination. It efficiently reduced the bacterial population and helped in suppressing the disease-causing ability of the bacteria. A study reported that $74 \%$ germination percentage was achieved, when seeds of flamingo lily (Anthurium andraeanum) were surface sterilized with $1 \%$ bleach for $20 \mathrm{~min}$ (Maira, Alexander, \& Vargas, 2010; Vargas, Mejías, Oropeza, \& De García, 2004). Bleach (50\% for $20 \mathrm{~min}$ ) has an effective sterilization effect when used on the shoot tips of young seedling of agarwood (Aquilaria hitra) under greenhouse condition (Hassan, Ali, Zainudin, \& Ismail, 2011). Rice seeds disinfected with bleach $(1000 \mathrm{ppm})$ resulted in a 2 to 3 log decrease in of aerobic plate counts (Piernas \& Guiraud, 1997). In another study application of bleach at $1000 \mathrm{ppm}$ was not effective against Escherichia coli, but a significant reduction in results was achieved with $2000 \mathrm{ppm}$ for 3 to $10 \mathrm{~min}$ (Taormina \& Beuchat, 1999). Rice seed treated with bleach solution at $60^{\circ} \mathrm{C}$ significantly reduced the aerobic plate counts (Piernas \& Guiraud, 1997). In another study at $200 \mathrm{ppm}$ of bleach completely precluded microbial growth, while maintaining the highest germination rate in radish after $72 \mathrm{~h}$ of sprouting (Fransisca, Zhou, Park, \& Feng, 2011). 


\section{Macrothink}

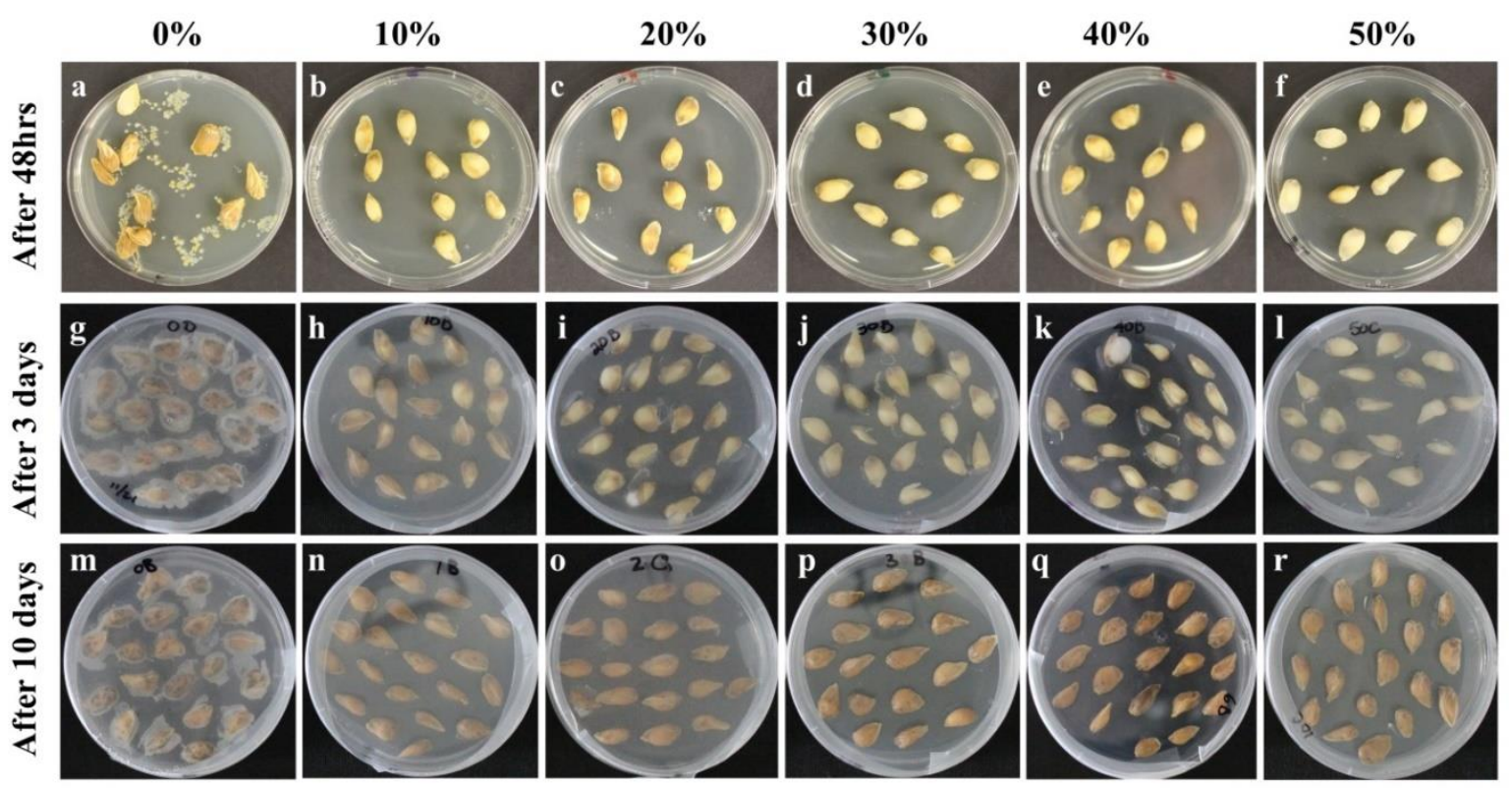

Figure 2. Decontamination efficiency of bleach at different concentration. (A-F) Pictorial view of citrus seeds taken after 48hrs of incubation; (G-L) pictorial view of citrus seeds taken after 3 days of incubation; (M-R) pictorial view of citrus seed taken after 10 days of incubation.

\section{Disinfection with Plant Preservative Mixture (PPM $\left.{ }^{\mathrm{TM}}\right)$}

Plant Preservative Mixture (PPM) was used for disinfection of orange seeds using different concentrations \{Compton, 2001 \#16\}Seeds treated with different concentration of PPM did not eliminate bacteria from the seeds. However, increasing the concentration of the PPM decreased the contamination in comparison with non-treated seeds (Fig. 3A- R). In the current study, PPM was applied in different concentration to disinfect the inoculated orange seeds. Orange seeds exposed to a high concentration of PPM were entirely free from the microbial contamination, while at low levels contamination was observed (Fig. 3). High doses of PPM against phytopathogenic bacteria are highly effective, but in view of potential phytotoxicity the plants should be exposed for a short period. An inverse relationship of PPM concentration was found on cauliflower micro shoots development. The higher the concentration, the lower the micro shoots (Rihan, Al-Issawi, Al-Swedi, \& Fuller, 2012). In another study it was found that the number of embryos per explant was decreased when incubated in embryo initiation media containing more than 5ml/L PPM (Compton \& Koch, 2001). Continuous application of PPM at $5 \mathrm{ml} / \mathrm{L}$ for controlling bacterial infection of explants has minimal phytotoxicity (Niedz \& Bausher, 2002) and had a positive effect on seedling growth of artificial seeds of marijuana (Cannabis sativa) (Lata, Chandra, Khan, \& ElSohly, 2009). 


\section{Macrothink}

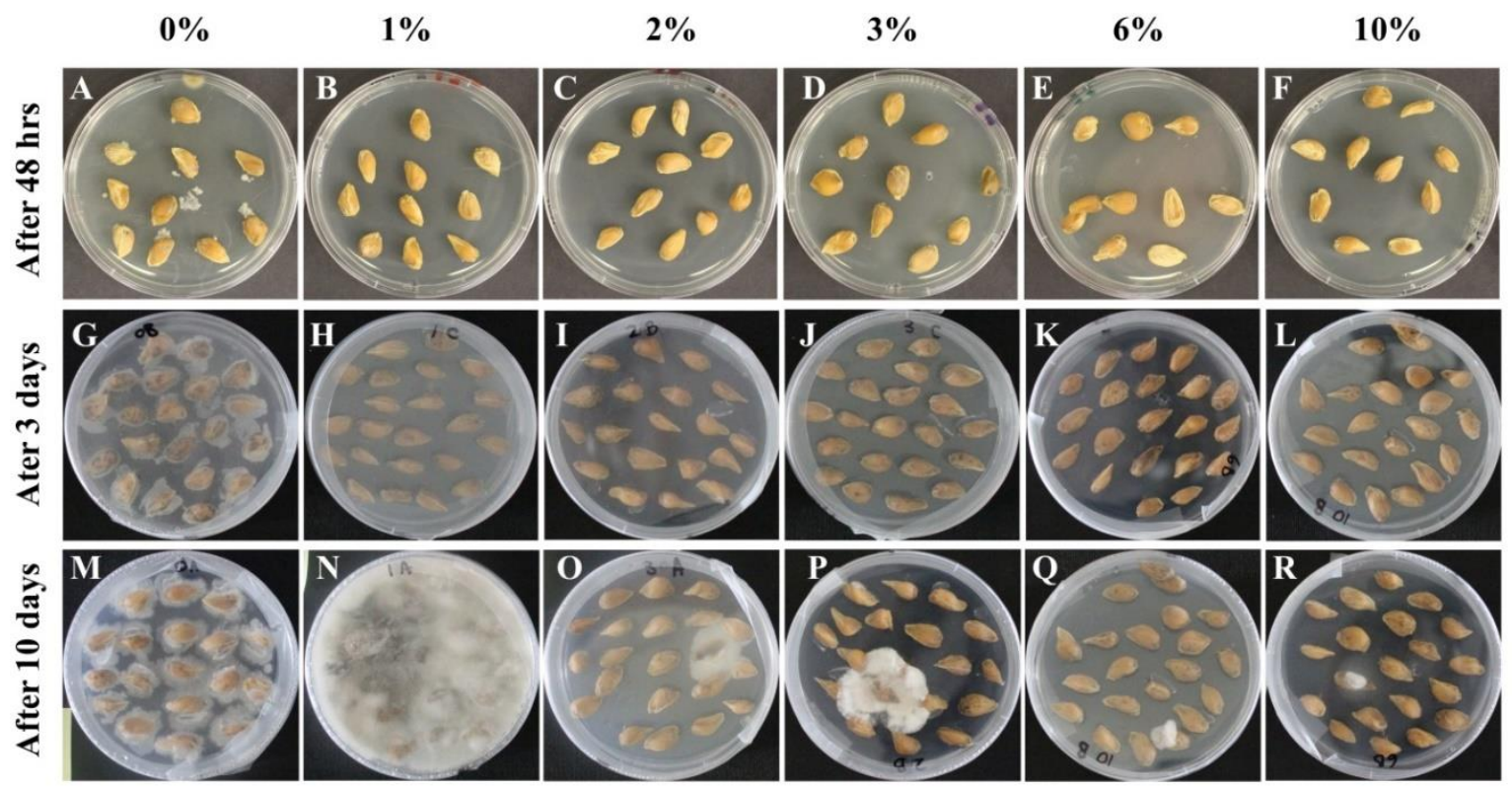

Figure 3. Effect of different concentration of PPM on contamination of citrus seeds. (A-F) Pictorial view of citrus seeds taken after $48 \mathrm{hrs}$ of treatment; (G-L) pictorial view of citrus seeds taken after 3 days of treatment; (M-R) pictorial view of citrus seeds taken after 10 days of treatment. Each treatment was repeated three times

\section{Decontamination with hot water treatment}

Thermotherapy method yielded the best result in reducing the level of bacterial pathogens without killing the seed. Hot water treatments of inoculated orange seeds were performed to assess the decontamination potential and germination yield. Seeds were subjected to different temperature. It was observed that at low temperature the bacterial contamination was high, whereas at high temperature the contamination was inversely proportional to interval (Fig. 4A-J). Although the high temperature and longer period efficiently reduced the bacterial contamination (Fig. 4K-T), it also decreased the percentage of seed germination. Seeds exposed to high temperature denatured certain enzymes and DNA (Black \& Bewley, 2000). However, hot water treatment with medium temperature increased the process of imbibition in seeds and stimulated germination related activities such as RNA synthesis, DNA replication, gibberellic acid synthesis and protein synthesis, which resulted in weakening the endosperm and thereby increasing the germination of the seed (Black \& Bewley, 2000). In agreement with previous studies, our results demonstrate that synchronized germination of inoculated orange seeds can be induced with the application of hot water treatment (Wood, Pritchard, \& Amritphale, 2000). A study reported that treatment of bell pepper seeds with hot water increased the seed quality parameters significantly (Musazura \& Bertling, 2012). It is also reported that an increase of temperature ranging between $45-53^{\circ} \mathrm{C}$ decreased the seed viability with no significant effect on seed vigor, whereas temperature higher than $53-55^{\circ} \mathrm{C}$ reduced seed germination (Lewis Ivey \& Miller, 2004). Hot water disinfection for a long time $\left(60^{\circ} \mathrm{C}\right.$ for $\left.30 \mathrm{~min}\right)$ decreased the germination percentage and emergence of rice varieties (Hsuan, Jhuang, Wu, \& Lur, 2019). Seeds of burdock (Prosopis) species treated with boiling 


\section{Macrothink Institute ${ }^{T M}$}

water increased the germination (Pasiecznik, Harris, Tavares, \& Cassama, 1998). Treatment of mung bean seeds (Vagna radiata) using thermal heat $\left(55\right.$ to $80^{\circ} \mathrm{C}$ for 2 to $20 \mathrm{~min}$ ) completely eradicated the E. coli and Salmonella spp. population greater than 5-log with no significant reduction in germination percentage (Weiss \& Hammes, 2005).

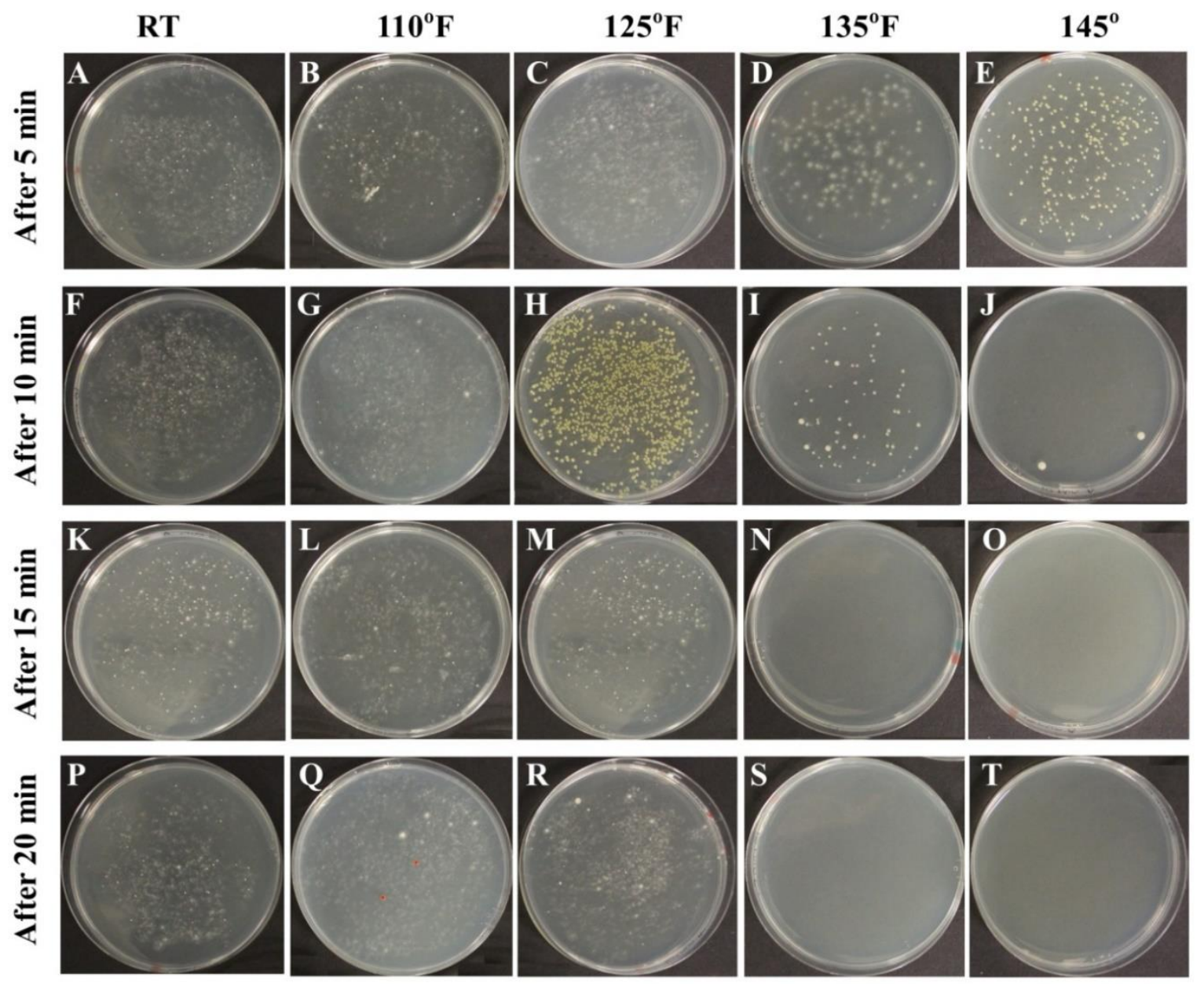

Figure 4. Hot water treatment of contaminated citrus seeds at different time intervals i.e. 5, 10, 15, and 20 minutes. (A-E) 5 min time interval with different temperature range; (F-J) 10 min time interval with different temperature range; $(\mathrm{K}-\mathrm{O}) 15$ min time interval with different temperature range; (P-T) 20 min time interval with different temperature range

\section{Optimum concentration of bleach and PPM}

All non-treated controls displayed fungal growth after 3 days of incubation on plates, but no bacterial colonies. None of the seeds germinated for up to 1 month. The highest percent germination was $(85.18 \%)$ recorded for bleach (Fig. 5B), whereas the highest germination percentage was $(62.96 \%)$ recorded for PPM (Fig. 5A).

\section{Determination of the effect of different treatment on seed germination and plant growth}

When seeds were planted to check the germination potential, the highest germination rate was from the seeds treated with $6 \%$ of PPM with a mean percent germination value 62.96 


\section{MInstitute ${ }_{\text {Mink }}^{\text {Macrothink }}$}

followed by $10 \%$ PPM with a mean percent germination value 59.26 (Fig. 5A). The highest seedling length was reported at $10 \%$ PPM with mean values of $6.63 \mathrm{~cm}$ with $\mathrm{p}=0.017$ (Fig. 5D \& G). The highest numbers of germinated seeds were obtained from seeds treated with bleach (30\%) giving a mean percent germination value of 85.18 followed by 50\% concentration giving a mean percent germination value of 77.78 (Fig. 5B). Highest seedling length with a mean value of $5.94 \mathrm{~cm}$ with $\mathrm{p}=0.23$ (Fig. $5 \mathbf{E} \& \mathbf{H}$ ). Analysis of hot water treatment revealed that that highest seed germination percentage (66.67) was observed in seed treated at $135^{\circ} \mathrm{F}$ for $15 \mathrm{~min}$ followed by seed treated at $125^{\circ} \mathrm{F}$ for $15 \mathrm{~min}$ (Fig. 5C). Highest seedling length with mean values of $5.99 \mathrm{~cm}$ with $\mathrm{p}=0.003$ was observed when treated at $125^{\circ} \mathrm{F}$ for $15 \mathrm{~min}$ and the lowest seedling length with a mean value of $3.33 \mathrm{~cm}$ was observed when treated with $145^{\circ} \mathrm{F}$ for $10 \mathrm{~min}$ (Fig. 5F \& I).
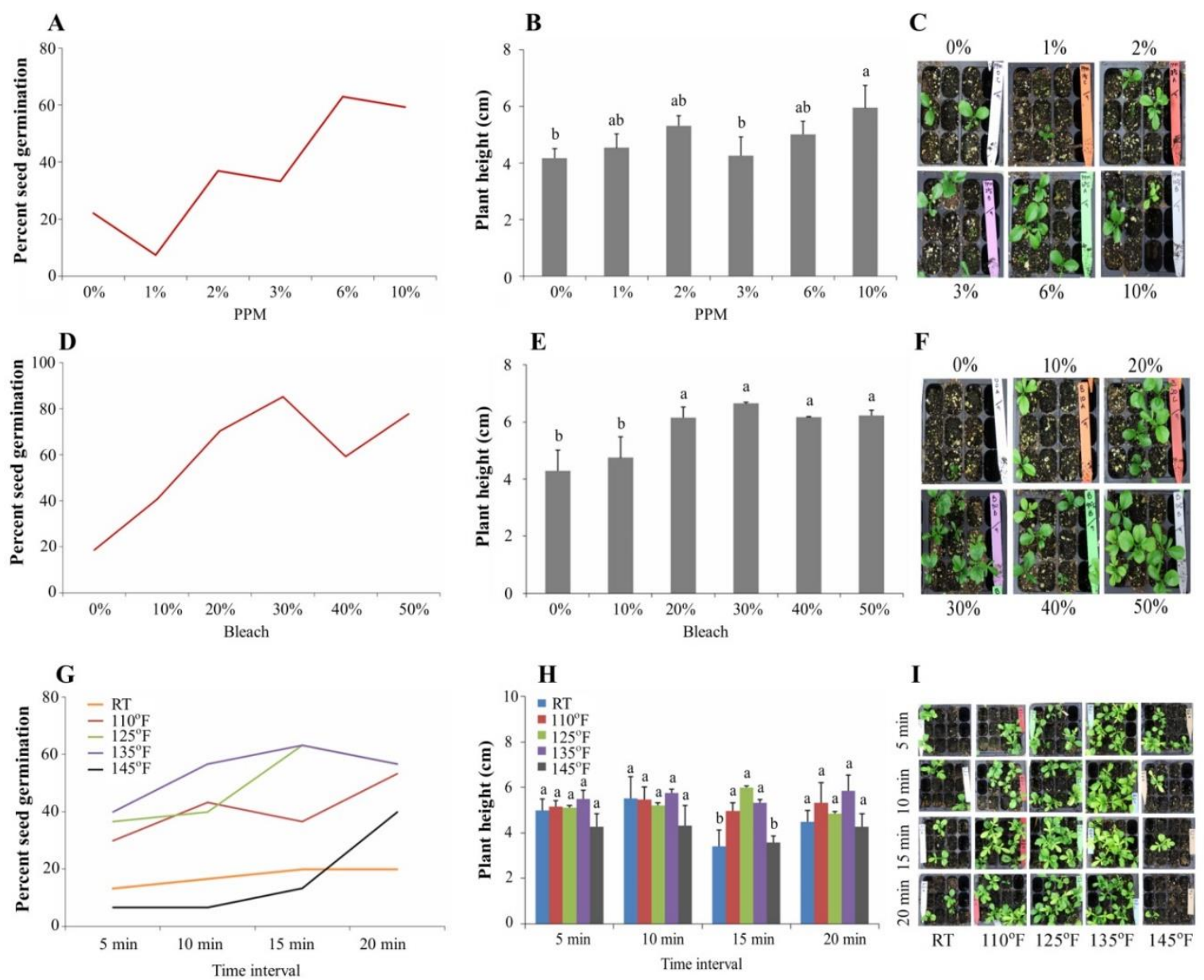

Figure 5. Effect of different treatments on germination rate and plant height of citrus seeds.

(A-C) Graphical representation showing effect of different concentrations of PPM on germination and plant height (D-F) Graphical representation showing effect of different concentrations of bleach on germination and plant height (G-I) Graphical representation showing effect of different concentrations of hot water treatment on germination and plant height

Data was statistically analyzed and the small alphabetical letters (a \& b) above the bars show 


\section{MInstitute Macrothink}

the significant differences $(\mathrm{P}<0.05)$ among treatments. Each experiment was repeated three times.

\section{Determination of different treatment on bacterial CFU}

Significant reduction (1.75and $1.07 \log \mathrm{CFU} / \mathrm{ml}$ ) of pathogen $\mathrm{X}$. citri was achieved in rinse water plates with $10 \%$ bleach and10\% PPM, respectively. In seed plates count significant reduction $(1.15$ and $0.19 \log \mathrm{CFU} / \mathrm{ml})$ of pathogen was recorded with $10 \%$ and $2 \%$ of bleach and PPM, respectively. Seeds treated with $20 \%$ and $6 \%$ of bleach and PPM completely eradicated the bacterial population from the seed plates count (Table 1).

Table 1. Effect of different concentration on colony forming unit after 48 hours of incubation at $37^{\circ} \mathrm{C}$ on NA plates

\begin{tabular}{|c|c|c|c|c|c|}
\hline \multirow[b]{2}{*}{ Conc: } & \multicolumn{2}{|c|}{ Sodium Hypochlorite } & \multirow[b]{2}{*}{ Conc: } & \multicolumn{2}{|c|}{ Plant Preservative Mixture (PPM) } \\
\hline & $\begin{array}{l}\text { Log CFU/ml } \pm \\
\text { SEM (RWPC) }\end{array}$ & $\begin{array}{l}\text { Log CFU/ml } \pm \\
\text { SEM (SPC) }\end{array}$ & & $\begin{array}{l}\text { Log CFU/ml } \\
\text { SEM (RWPC) }\end{array}$ & $\begin{array}{l}\text { Log CFU/ml } \\
\text { SEM (SPC) }\end{array}$ \\
\hline $0 \%$ & $6.15 \pm 0.30^{\mathrm{a}}$ & $4.40 \pm 1.57^{\mathrm{a}}$ & $0 \%$ & $6.09 \pm 0.34^{\mathrm{a}}$ & $5.47 \pm 0.08^{a}$ \\
\hline $10 \%$ & $4.40 \pm 0.31^{\mathrm{b}}$ & $3.25 \pm 1.15^{b}$ & $1 \%$ & $5.77 \pm 0.04^{\mathrm{ab}}$ & $5.34 \pm 0.07^{\mathrm{ab}}$ \\
\hline $20 \%$ & $0^{c}$ & $0^{c}$ & $2 \%$ & $5.70 \pm 0.09^{\mathrm{ab}}$ & $5.28 \pm 0.04^{b}$ \\
\hline $30 \%$ & $0^{\mathrm{c}}$ & $0^{\mathrm{c}}$ & $3 \%$ & $5.68 \pm 0.09^{\mathrm{ab}}$ & $5.08 \pm 0.07^{\mathrm{c}}$ \\
\hline $40 \%$ & $0^{\mathrm{c}}$ & $0^{\mathrm{c}}$ & $6 \%$ & $5.64 \pm 0.12^{\mathrm{ab}}$ & $0^{\mathrm{d}}$ \\
\hline $50 \%$ & $0^{\mathrm{c}}$ & $0^{\mathrm{c}}$ & $10 \%$ & $5.20 \pm 0.05^{b}$ & $0^{\mathrm{d}}$ \\
\hline
\end{tabular}

Data were statistically analyzed and the small alphabetical letters $(a, b, c \ldots)$ in the same column shows the significant differences $(P<0.05)$ among treatments. Each experiment was performed in triplicate. $\quad \mathrm{RWPC}=$ Rinse water plate count; $\mathrm{SPC}=$ Seeds plate count

Exposure of inoculated seeds to hot water at $135^{\circ} \mathrm{F}$ and $145^{\circ} \mathrm{F}$ for $5 \mathrm{minhad}$ significant reduction ( 0.88 and $1.12 \log \mathrm{CFU} / \mathrm{ml})$ of pathogen population, respectively. Whereas, seeds treated with hot water at $125^{\circ} \mathrm{Ffor} 15 \mathrm{~min}$ significantly reduced $(0.23 \log \mathrm{CFU} / \mathrm{ml})$ of the bacterial population. Seeds treated with hot water at $135^{\circ}$ Fand $145^{\circ}$ Ffor 15 and 20 min completely eradicated the pathogen population (Table 2).

Table 2. Effect of time interval and temperature on total number of bacterial count after 48 hours of incubation at $37^{\circ} \mathrm{C}$ on NA plates

\begin{tabular}{l|c|c|c|c|r}
\hline \multirow{2}{*}{$\begin{array}{c}\text { Time } \\
\text { interval }\end{array}$} & Room & \multicolumn{1}{c|}{$110^{\circ} \mathrm{F}$} & \multicolumn{1}{c|}{$125^{\circ} \mathrm{F}$} & $135^{\circ} \mathrm{F}$ & $145^{\circ} \mathrm{F}$ \\
\cline { 2 - 6 } & $\log$ CFU/ml & $\log \mathrm{CFU} / \mathrm{ml}$ & $\log \mathrm{CFU} / \mathrm{ml}$ & $\log \mathrm{CFU} / \mathrm{ml}$ & $\log \mathrm{CFU} / \mathrm{ml}$ \\
\hline $5 \mathrm{~min}$ & $6.80 \pm 0.062^{\mathrm{a}}$ & $6.71 \pm 0.041^{\mathrm{a}}$ & $6.54 \pm 0.044^{\mathrm{a}}$ & $5.92 \pm 0.291^{\mathrm{b}}$ & $5.68 \pm 0.298^{\mathrm{b}}$ \\
\hline $10 \mathrm{~min}$ & $6.66 \pm 0.022^{\mathrm{a}}$ & $6.64 \pm 0.017^{\mathrm{a}}$ & $6.48 \pm 0.046^{\mathrm{a}}$ & $5.33 \pm 0.348^{\mathrm{b}}$ & $5.07 \pm 0.507^{\mathrm{b}}$ \\
\hline $15 \mathrm{~min}$ & $6.57 \pm 0.021^{\mathrm{a}}$ & $6.46 \pm 0.029^{\mathrm{b}}$ & $6.34 \pm 0.053^{\mathrm{c}}$ & $0^{\mathrm{d}}$ & $0^{\mathrm{d}}$ \\
\hline $20 \mathrm{~min}$ & $6.53 \pm 0.038^{\mathrm{a}}$ & $6.47 \pm 0.057^{\mathrm{a}}$ & $6.33 \pm 0.045^{\mathrm{b}}$ & $0^{\mathrm{c}}$ & $0^{\mathrm{c}}$ \\
\hline
\end{tabular}

Data were statistically analyzed and the small alphabetical letters (a, b, c...) in the same row shows the significant differences $(P<0.05)$ among treatments. Each experiment was performed in triplicate. 


\section{Conclusion}

This research was designed to study the effects of various treatments in decontamination of orange seeds from $X$. citri. Our finding showed that the hot water and treatment with common household bleach, was very effective in eliminating most bacterial contamination from orange seeds. We propose that seeds treated with bleach and hot water play an effective role in eliminating the pathogen populations, positively enhanced the germination percentage and plant height of orange seeds under greenhouse conditions.

\section{Acknowledgement}

We are thankful to Mary Brennan (MREC Florida) for help with funds and with bacterial culture.

\section{References}

Black, M., \& Bewley, J. D. (2000). Seed technology and its biological basis: Crc Press.

Brunings, A. M., \& Gabriel, D. W. (2003). Xanthomonas citri: breaking the surface. Molecular plant pathology, 4(3), 141-157. https://doi.org/10.1046/j.1364-3703.2003.00163.x

Canteros, B. (2004). Management of citrus canker in Argentina. A review. Paper presented at the Proceedings of the International Society for Citriculture.

Compton, M. E., \& Koch, J. M. (2001). Influence of plant preservative mixture (PPM) TM on adventitious organogenesis in melon, petunia, and tobacco. Vitro Cellular \& Developmental Biology-Plant, 37(2), 259-261. https://doi.org/10.1007/s11627-001-0046-6

Ference, C. M., Gochez, A. M., Behlau, F., Wang, N., Graham, J. H., \& Jones, J. B. (2018). Recent advances in the understanding of Xanthomonas citri ssp. citri pathogenesis and citrus canker disease management. Molecular plant pathology, 19(6), 1302. https://doi.org/10.1111/mpp.12638

Fransisca, L., Zhou, B., Park, H., \& Feng, H. (2011). The effect of calcinated calcium and chlorine treatments on Escherichia coli O157: H7 87-23 population reduction in radish sprouts. Journal of food science, 76(6), M404-M412. https://doi.org/10.1111/j.1750-3841.2011.02270.x

Gabriel, D., Kingsley, M., Hunter, J., \& Gottwald, T. (1989). Reinstatement of Xanthomonas citri (ex Hasse) and X. phaseoli (ex Smith) to species and reclassification of all X. campestris pv. citri strains. International Journal of Systematic and Evolutionary Microbiology, 39(1), 14-22. https://doi.org/10.1099/00207713-39-1-14

Gottwald, T. R., Graham, J. H., \& Schubert, T. S. (2002). Citrus canker: the pathogen and its impact. Plant Health Progress, 3(1), 15. https://doi.org/10.1094/PHP-2002-0812-01-RV

Hassan, N. H., Ali, N. A. M., Zainudin, F., \& Ismail, H. (2011). Effect of 6-benzylaminopurine (BAP) in different basal media on shoot multiplication of Aquilaria hirta and detection of essential oils in the in vitro shoots. African Journal of Biotechnology, 10(51), 10500-10503. https://doi.org/10.5897/AJB11.121 


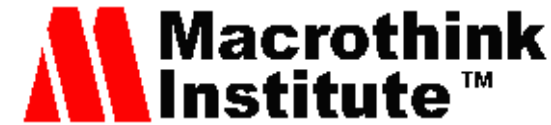

Journal of Agricultural Studies

ISSN 2166-0379

2020, Vol. 8, No. 4

Hsuan, T. P., Jhuang, P. R., Wu, W. C., \& Lur, H. S. (2019). Thermotolerance evaluation of Taiwan Japonica type rice cultivars at the seedling stage. Botanical Studies, 60(1), 29. https://doi.org/10.1186/s40529-019-0277-7

Lata, H., Chandra, S., Khan, I. A., \& ElSohly, M. A. (2009). Propagation through alginate encapsulation of axillary buds of Cannabis sativa L.-an important medicinal plant. Physiology and Molecular Biology of Plants, 15(1), 79-86. https://doi.org/10.1007/s12298-009-0008-8

Lewis Ivey, M. L., \& Miller, S. A. (2004). Evaluation of hot water seed treatment for the control of bacterial leaf spot and bacterial canker on fresh market and processing tomatoes. Paper presented at the I International Symposium on Tomato Diseases 695. https://doi.org/10.17660/ActaHortic.2005.695.22

Maira, O., Alexander, M., \& Vargas, T. E. (2010). Micropropagation and organogenesis of Anthurium andreanum Lind cv Rubrun. In Protocols for In Vitro Propagation of Ornamental Plants (pp. 3-14): Springer. https://doi.org/10.1007/978-1-60327-114-1_1

Mei, P. Y., Zhou, Y., Li, Z. A., \& Zhou, C. Y. (2020). New insights into the resistance of four citrus genotypes to Xanthomonas citri subsp. citri. Journal of Plant Pathology, 1-7. https://doi.org/10.1007/s42161-020-00493-7

Musazura, W., \& Bertling, I. (2012). Investigation into the effect of multiple hot water treatment of tomato (Solanum lycopersicum) and pepper (Capsicum annuum) seeds on seed viability and seed vigour. Paper presented at the II All Africa Horticulture Congress 1007. https://doi.org/10.17660/ActaHortic.2013.1007.94

Niedz, R. P., \& Bausher, M. G. (2002). Control of in vitro contamination of explants from greenhouse-and field-grown trees. In Vitro Cellular \& Developmental Biology-Plant, 38(5), 468-471. https://doi.org/10.1079/IVP2002316

Okudera, Y., \& Ito, M. (2009). Production of agarwood fragrant constituents in Aquilaria calli and cell suspension cultures. Plant Biotechnology, 26(3), 307-315. https://doi.org/10.5511/plantbiotechnology.26.307

Orbović, V., Dutt, M., \& Grosser, J. W. (2013). Evaluation of the germination potential of citrus seeds during the harvesting season. HortScience, 48(9), 1197-1199. https://doi.org/10.21273/HORTSCI.48.9.1197

Pasiecznik, N., Harris, P., Tavares, J. d. P., \& Cassama, M. (1998). Pretreatment of Prosopis seeds to break dormancy. International Tree Crops Journal, 9(3), 187-193. https://doi.org/10.1080/01435698.1998.9752974

Piernas, V., \& Guiraud, J. (1997). Disinfection of rice seeds prior to sprouting. Journal of food science, 62(3), 611-615. https://doi.org/10.1111/j.1365-2621.1997.tb04443.x

Rihan, H. Z., Al-Issawi, M., Al-Swedi, F., \& Fuller, M. P. (2012). The effect of using PPM (plant preservative mixture) on the development of cauliflower microshoots and the quality of artificial seed produced. Scientia horticulturae, 141, 47-52. https://doi.org/10.1016/j.scienta.2012.03.018 
Taormina, P. J., \& Beuchat, L. R. (1999). Comparison of chemical treatments to eliminate enterohemorrhagic Escherichia coli O157: $\mathrm{H} 7$ on alfalfa seeds. Journal of food protection, 62(4), 318-324. https://doi.org/10.4315/0362-028X-62.4.318

Thakre, B., Soni, U., Gour, C., Vishwakarma, R., \& Jashwani, N. (2017). Field Identification, Eradication And Current Management Of Citrus Canker Caused By Xanthomonas Campestris Pv. Citriin Satpura Platun Of Madhya Pradesh, India. Plant Archives, 17(1), 371-374.

Vargas, T. E., Mejías, A., Oropeza, M., \& De García, E. (2004). Plant regeneration of Anthurium andreanum cv Rubrun. Electronic Journal of Biotechnology, 7(3), 10-11. https://doi.org/10.2225/vol7-issue3-fulltext-11

Weiss, A., \& Hammes, W. P. (2005). Efficacy of heat treatment in the reduction of salmonellae and Escherichia coli O157: $\mathrm{H}-$ on alfalfa, mung bean and radish seeds used for sprout production. European Food Research and Technology, 221(1-2), 187-191. https://doi.org/10.1007/s00217-004-1125-9

Wood, C. B., Pritchard, H. W., \& Amritphale, D. (2000). Desiccation-induced dormancy in papaya (Carica papaya L.) seeds is alleviated by heat shock. Seed Science Research, 10(2), 135-145. https://doi.org/10.1017/S0960258500000143

\section{Copyright Disclaimer}

Copyright for this article is retained by the author(s), with first publication rights granted to the journal.

This is an open-access article distributed under the terms and conditions of the Creative Commons Attribution license (http://creativecommons.org/licenses/by/4.0/). 